\title{
Eco-Fer (Ecotru Fixed Bed Reactor) : Application of Ecotru on Fixed Bed Reactor for Eliminating Ammonium in Waste Water
}

\author{
Hana Syakira, Lidiya Novelendah, Kartika Pertiwi, Rusyda Syahidah, Purwono and Titik Istirokhatun* \\ Environmental Engineering Department, Faculty of Engineering, Diponegoro University, Semarang - Indonesia
}

\begin{abstract}
Ammonium, a form of nitrogen, causes eutrophication and also can be toxic for fish. The existence of ammonium in surface water arises from human and animal waste, as well as from organic materials oxidation derived from industrial or residential wastewater. Consequently, wastewater with high ammonium content must be processed properly prior to disposal. One of the commonly used treatments for wastewater is attached biological wastewater treatment, which can be applied with a fixed bed reactor. Fixed bed reactor was being inoculated with ecotru bacteria which were fed with artificial wastewater containing ammonium of $50 \mathrm{mg} \mathrm{NH}{ }^{4+}-\mathrm{N} / \mathrm{L}$. In this study, it was found that the microorganisms contained in ecotru are Geobacillus toebii bacteria. The ammonium removal efficiency was $99,63 \%$ and the way Geobacillus toebii contribute on ammonium removal was experimentally studied in this study.
\end{abstract}

Keywords: ammonium; ecotru bacteria; fixed bed reactor

\section{Introduction}

Ammonium evidently takes place naturally in low concentrations in uncontaminated waterways [1]. Waste water containing ammonium can be derived from secretions of mammalian (as urine). However, pollution impacts of agricultural, runoff, industrial and domestic effluent also play an important role in ammonium contamination of groundwater and surface water resources $[2,3]$.

Ammonium in high concentration can be toxic and may intervene aesthetically due to the fact that it could produce a pungent odor and eutrophication within the surrounding region [4]. Furthermore, natural nitrification in wastewater which is rich in ammonium would be inhibited. This condition triggers algal blooms which contribute to hypoxic and anoxic conditions in surface waters, which result in poisoned fish, reduce the purification capability of water, highly undesirable changes in ecosystem structure and function and subsequently harm the water environment $[5,3,6,7]$.

Ammonia $\left(\mathrm{NH}_{3}\right)$ and Ammonium $\left(\mathrm{NH}_{4}{ }^{+}\right)$are spontaneously exchangeable depending on the $\mathrm{pH}$ and temperature of urban and natural waters [8]. $\mathrm{NH}_{3}$, as a neutral molecule, is much more toxic than ammonium [9] due to its ability to diffuse across the epithelial membrane of aquatic organisms much more easily than the ionized ammonia. Ammonia could block the process of oxygen transfer in the gills of fish. Ammonia poisoned fish appear lethargic and come up to the surface of the water gasping for air [10]. Moreover, the damaged gill epithelia can also cause asphyxiation, stimulate glycolysis, and causes Krebs cycle suppression which leads to acidosis continuously which then decreases the ability of blood oxygen-carrying, disturbs blood vessels, and lowering the function of kidney and liver [11]. Nonetheless, concentration of ammonium in natural waters is much more than ammonia due to the circum-neutral $\mathrm{pH}$ predominance [3]. Based on the quality standar, the limit level of ammonia in the marine environment is $1 \mathrm{mg} / \mathrm{L}$ [12]. According to the Ministerial Regulation Environment and Forestry of the Republic of Indonesia, number P.68/Menlhk/Setjen/Kum.1/8/2016 on the Quality Standards of Domestic Wastewater, the maximum content of ammonia is $10 \mathrm{mg} / \mathrm{l}$. Therefore, due to its potential risk, wastewater with high concentration of ammonium must be processed first before discharge to the environment for reuse purposes [13].

There are many approaches to treat waste water that may be used to eliminate ammonium both in physical, chemical, and biological. Based on two categories of biological processing, namely suspended growth and fixed film, biological treatment can be done by sequencing batch reactor and fixed bed reactor [14]. The inherent fixed film system has better microorganisms activity compared to the suspended growth system. This is because the microorganisms that form the biofilm layer have a low substrate concentration and provide a higher possible reaction with nutrients outside the substrate [15].

\footnotetext{
${ }^{*}$ titik.istirokhatun@,live.undip.ac.id
} 
Ecotru contains active microorganisms that create enzymes as a super catalyst and cofactor of decomposing various unwanted compounds such as oils, fats, proteins, carbohydrates, cellulose, and various types of pollutants. Ecotru consists of $100 \%$ natural ingredients and performs biodegradation without the addition of chemicals. Its uses leave no residues. It also has the ability to reduce the concentration of COD, BOD, ammonia, TSS, phosphate, and other contaminants. However, little attention was paid to the ability of Ecotru to remove pollutants, especially ammonium [16].

In this research, ecotru bacteria was used to eliminate ammonium on fixed bed reactor. The aim of this study is to determine the efficiency of ammonium removal by bacteria in the reactor. Bacteria identification test and a series of concentration tests of ammonium, nitrite, nitrate, and $\mathrm{pH}$ were also conducted.

\section{Methods}

This research has been conducted in May to July 2018 at Environmental Laboratory, Department Environmental Engineering and Central Laboratory of Research and Service-Diponegoro University, Semarang - Indonesia.

\subsection{Bacteria Identification}

In this study, bacteria identification is needed to determine the specific type of bacteria in ecotru that has ability to eliminate ammonium in waste water. To identify and analyze the specific type of bacteria in ecotru, the fluorescent method with VITEK 2 Compact tool was used. Before identification using this tool, ecotru was first isolated by gram-painting techniques to ascertain the type of bacteria, whether gram-positive or gram-negative bacteria. Gram-positive bacteria binds strongly with violet crystal compounds, so that in relief with alcohol, the color of purple that appears does not fade $[17,18]$.

The isolated colonies of bacteria were taken using a spherical wire and fed into a reaction tube containing 3 $\mathrm{ml}$ of $0.45 \%$ sodium chloride, then homogenized. Then the turbidity level of the suspension is measured by Mc Farland 0.50-0.60 standard using a density tool. Dilutions of the suspension were then made on the other tubes. As much as 280 microliter suspension was inserted into a reaction tube containing $3 \mathrm{ml}$ of $0.45 \%$ sodium chloride, which then was homogenized. In the first suspension tube, biochemical cassette with GP code was inserted, while on the second suspension tube sensitivity cassette with AST GP code was inserted [19, $20]$.

\subsection{Experimental Setup}

In this study, fixed bed reactor was used due to its ability to attach inherent biofilm strongly in the media and also microorganisms could be concentrated in the reactor while performance of reactor increases [21].

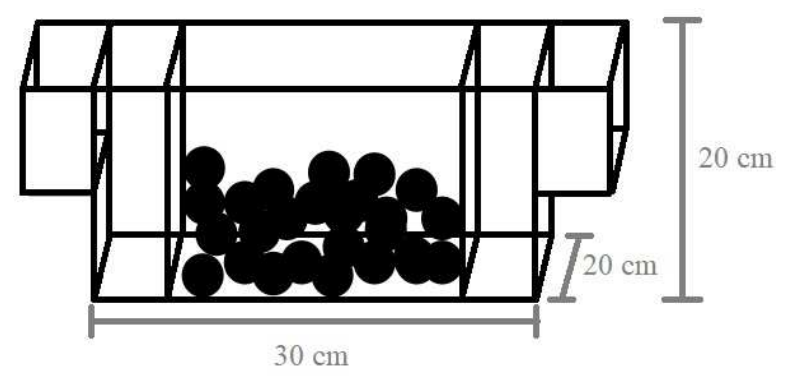

Fig. 1 Fixed Bed Reactor Design

Fixed Bed Reactor (Fig 1) was made from glass material with capcity $14 \mathrm{~L}$. Bioballs (diameter $3 \mathrm{~cm}$ ) were inserted to the $30 \%$ of reactor volume as microorganisms growth media. Small diameter was chosen in order to minimize the blockage. In the reactor there is also an aerator as an oxygen supplier and an airstone to spread oxygen evenly.

\subsection{Reactor Batch System test}

In this experiments, the fixed bed reactor was batchoperated for 14 days. Before this process was done, the bacteria was first activated by mixing 14 grams of ecotru bacteria into $1 \mathrm{~L}$ water. The mixture was then allowed to stand for about 12-24 hours before being poured into a 14-L reactor. In the use of ecotru bacteria, a mixture of 10 grams of ecotru bacteria in 1 liter of water can actually be used for 1 cubic meter of wastewater, but to support this research so that the ecotru bacteria can be more visible and the ammonium removal process takes place in accordance with the planned time, 14 grams of ecotru bacteria were used in $1 \mathrm{~L}$ of water for 14 liters of wastewater. During this test, the conditions in the reactor were operated aerobic by keeping the concentration, temperature, and $\mathrm{pH}$. The artificial waste water of $50 \mathrm{mg} / 1 \mathrm{NH}^{4+}-\mathrm{N}$ and $350 \mathrm{mg} / 1 \mathrm{NaHCO}_{3}$ were fed to ecotru bacteria during analyses processes and the measurement of removal ammonium.

\section{Results and Discussion}

\subsection{Geobacillus toebii}

From the analysis sheet printed by Vitek 2, the identified bacteria in ecotru was Geobacillus toebii. The likelihood of the test result validity was $91 \%$. Geobacillus toebii is a thermophilic bacterium which first isolated from hay compost. It is an aerobic, grampositive, motile and rod-shaped bacteria. Its cell length is 2.0-3.5 $\mu \mathrm{m}$ and the cell width is $0.5-0.9 \mu \mathrm{m}$ [22].

Listed in the table of biochemical details, in the analysis result sheet, Geobacillus toebii has a positive indication on APPA, ESC, and PSCNa. Especially in APPA, APPA is Ala-Phe-Pro-arylamidase, which indicates that Geobacillus toebii produces enzymes that acts as catalyst the oxidation process. The existence of the enzyme explain how Geobacillus toebii was able to reduce ammonium levels in artificial waste water in this study. 
According to Metcalf and Eddy (1991), biological nitrogen removal can be done through the process of nitrification and denitrification [14]. Nitrification takes place in two successive oxidation stages, namely the oxidation of ammonium to nitrite (nitritation) and the oxidation of nitrite to nitrate (nitratation) with oxygen. In this study, Geobacillus toebii utilized the presence of ammonium, then nitrite, as sources of energy, oxygen as an electron acceptor, and carbon dioxide as a carbon source [21].

\subsection{Ammonium Removal Efficiency}

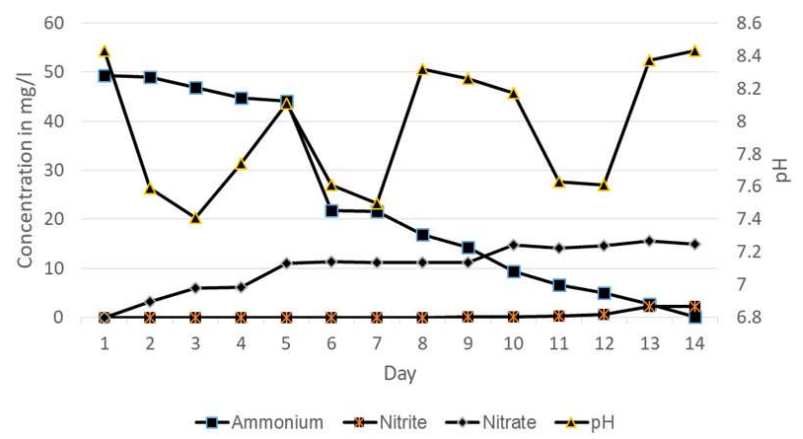

Fig 2. Nitrification Process in Fixed Bed Reactor

Based on data in figure 2, ammonium concentrations have decreased on the second day and continue to decline until day 14. This indicates that Geobacillus toebii has been able to adapt to the new environment in oxidizing ammonium. Increasing nitrate concentrations also began to occur on the second day. Nitrate concentrations tend to continue to increase with small fluctuations. The highest accumulation of nitrite occurred on day 13 with a value of $2.27 \mathrm{mg} \mathrm{NO} 2-\mathrm{N} / 1$. This indicates that Geobacillus toebii has been able to adapt to the new environment in oxidizing nitrites. When calculated, the amonium removal efficiency was $99.63 \%$.

Initially, the decline in ammonium concentration occured slightly. This situation was consistent with the phase of bacterial life at the initial growth (stationary phase) where bacterial growth is not too much so that the ammonium removal process on the initial day was not significant. In this study, parameters measured in addition to ammonium were nitrite, nitrate, and $\mathrm{pH}$. The measurement of nitrite and nitrate were carried out to ensure that the reduced ammonium concentration was due to the oxidation process that converts ammonium to nitrite and then nitrate (nitrification process). While $\mathrm{pH}$ measurement was done to control the life of bacteria. Geobacillus toebii grow best around $\mathrm{pH}$ values 6.0-9.0. Whereas in the fixed-bed reactor process, the measured $\mathrm{pH}$ range were in the range of 7.4-8.4. This indicated that during the ammonium removal process in the reactor, the bacterium Geobacillus toebii lived in an appropriate $\mathrm{pH}$.

\section{References}

1. E. Marañón, M. Ulmanu, Y. Fernandez, I. Anger, L. Castrillon, Removal of ammonium from aqueous solutions with volcanic tuff. J. Hazard Mater. 137, 1402-1409 (2006)

2. I. Riwayati, Decreasing Ammonia Content in Water by Electrolysis Using Stainless Steel Electrodes / Platinaeur. (Chemical Engineering Magister Diponegoro University, 2010). in Bahasa

3. J. Huang, N.R. Kankanamge, C. Chow, D.T. Welsh, T. Li and P.R. Teasdale, Removing ammonium from water and wastewater using costeffective adsorbents: A review. J. Env. Sci. 63, 174-197 (2018)

4. Titiresmi, N. Sopiah, Biofilter Technology for Ammonia Waste Treatment. J. Env. Eng. 7, 173179 (2006). in Bahasa

5. A. Bhatnagar, M. Sillanpaa, A review of emerging adsorbents for nitrate removal from water. Chem. Eng. J. 168, 493-504 (2011)

6. J.A. Camargo, Á. Alonso, Ecological and toxicological effects of inorganic nitrogen pollution in aquatic ecosystems: a global assessment. Env. Int. 32, 831-849 (2006)

7. V.H. Smith, G.D. Tilman, J.C. Nekola, Eutrophication: impacts of excess nutrient inputs on freshwater, marine, and terrestrial ecosystems. Environ. Pollut. 100, 179-196 (1999)

8. L.M.L. Nollet, Handbook of Water Analysis (CRC Press Inc., Florida, 2013)

9. G.E. Batley, S.L. Simpson, Development of guidelines for ammonia in estuarine and marine water systems. M. Env. Pollut. 58, 1472-1476 (2009)

10. X. Luo, Q. Yan, C. Wang, C. Luo, N. Zhou, C. Jian, Treatment of ammonia nitrogen wastewater in low concentration by two-stage ozonization. Int. J. Env. Research and Public Health. 12(9), 119751198 (2015)

11. T. Augspurger, A.E. Keller, M.C. Black, W.G. Cope, F.J. Dwyer, Water quality guidance for protection of freshwater mussels (Unionidae) from ammonia exposure. Env. Toxicol. Chem. 22, 2569-2575 (2003)

12. P.J. Udeh, A Guide to Healthy Drinking Water: All You Need to Know About the Water You Drink (iUniverse, Indiana, 2004)

13. D.T. Britto, H.J. Kronzucker, NH4+ toxicity in higher plants: a critical review. J. Plant Physiol. 159, 567-584 (2002)

14. Metcalf \& Eddy, Wastewater Engineering : Treatment, Disposal and Reuse 4th Edition (McGraw-Hill, New York, 2003)

15. Goh Chin-Ping, Chye-Eng Seng, Amat Ngilmi Ahmad Sujari, Poh-Eng Lim, Performance of sequencing batch biofilm and sequencing batch reactor in simultaneous p-nitrophenol and nitrogen removal. Env. Tech. 30, 725-736 (2009) 
16. R. Suganda, Decrease in the concentration of ammonia, nitrate, nitrite and COD in liquid waste using biofilms - Ponds of PVC wasps and coconut shells accompanied by the addition of Ecotru. J. Tek. Ling. 3, 4 (2014)

17. Biomerieux, Vitek 2 Technology Product Information (Lyon, 2013)

18. M.J. Pelczar, E.C.S. Chan, Basic of Microbiology (UI Press, Jakarta, 2005). in Bahasa

19. Biomerieux, Mc Farland Standard (Lyon, 2003)
20. M.J. Miller, Encyclopedia of Rapid Microbiological Methods (DHI Publishing, Illinois, 2005)

21. Sudarno, Development of Nitrifying Biofilms in Fixed Bed Reactors at High Salinity. Jurnal Presipitasi 9, 1 (2012). in Bahasa

22. M.H. Sung, H. Kim, J.W. Bae, S.K. Rhee, C.O. Jeon, K. Kim, J.J. Kim, S.P. Hong, S.G. Lee, J.H. Yoon, Y.H. Park, D.H. Baek, Geobacillus toebii sp. nov., a novel thermophilic bacterium isolated from hay compost. Int. J. of Syst. and Evo. Microbio. 52, 2251-2255 (2002) 